\title{
Hematological and immunological development from birth to six months of age in Holstein calves
}

\author{
[Desenvolvimento hematológico e imunológico em bezerros Holandeses do nascimento \\ aos seis meses de idade] \\ C.C. Baccili ${ }^{1}$, S.M.F.N. de Oliveira $^{1}$, J.F.R Costa ${ }^{1}$, C.O.Massoco ${ }^{1}$, C.R. Pozzi ${ }^{2}$, V. Gomes ${ }^{1}$ \\ ${ }^{1}$ Faculdade de Medicina Veterinária e Zootecnia Universidade de São Paulo - São Paulo, SP \\ ${ }^{2}$ Instituto de Zootecnia - Nova Odessa, SP
}

\begin{abstract}
The hematological and immunological development of calves from birth to 6 months of age was performed by hemogram and cellular phenotype. Ten male Holstein calves were assessed in 13 moments: before colostrum intake (D0), every 2 days until the $10^{\text {th }}$ day of life (D2 to D10), at the $15^{\text {th }}$ day after birth (D15), and then monthly up to 6 months (D180). Calves presented hemoconcentration on day (D) 0 and showed a gradual decrease in hematimetric rates until D180. The inversion of the neutrophilic for lymphocytic profile was observed on D4. The percentage of $\mathrm{CD}^{+}$cells on D10 was higher than D30 up to D180. The number of CD4 ${ }^{+}$ and $\mathrm{CD} 8^{+}$cells did not change between time points. The number of $\mathrm{CD} 21^{+}$lymphocytes was significantly higher at early time points of D0 up to D15, compared on D30 until D150. In conclusion, the neonatal period was marked by stress leukogram in the first 4 days, and low number of B lymphocytes. These might be risk factors for bacterial infections responsible for navel inflammation and diarrhea. The increase in the number of B cells from 30 days of age demonstrated that the calves were functional and able to generate an immune response.
\end{abstract}

Keywords: bovine, immune system, leukogram, immunophenotyping, flow cytometry

\section{RESUMO}

O desenvolvimento hematológico e o imunológico de bezerros do nascimento aos seis meses de idade foram avaliados por meio hemograma e imunofenotipagem dos linfócitos. Para tanto, 10 bezerros machos Holandeses foram avaliados em 13 momentos: antes da ingestão do colostro (DO), a cada dois dias até o $10^{\circ}$ dia (D2 a D10), $15^{\circ}$ dia (D15) e, em seguida, mensalmente até seis meses de idade (D180). Os bezerros apresentaram hemoconcentração em DO e decréscimo gradual dos índices hematimétricos até D180. A inversão do perfil neutrofílico para linfocítico foi observada em D4. Os valores de CD3+ (\%) em D10 foram maiores que aqueles observados em D30 até D180. $\mathrm{CD}^{+}$e $C D 8^{+}$não apresentaram alterações entre os momentos. Os linfócitos $\mathrm{B} C \mathrm{CD} 2 \mathrm{I}^{+}$aumentaram significativamente a partir dos primeiros momentos D0 até D15, em comparação com os momentos subsequentes D30 até D150. Em conclusão, o período neonatal foi caracterizado pelo leucograma de estresse nos primeiros quatro dias e o baixo número de linfócitos $B$. Esses fatos podem ser considerados como fatores de risco para infecções bacterianas responsáveis pelas inflamações umbilicais e pela diarreia. Por outro lado, o aumento de células B após os 30 dias de vida demonstrou que os bezerros foram capazes de gerar uma resposta imune.

Palavras-chave: bovino, sistema imune, leucograma, imunofenotipagem, citometria de fluxo

\section{INTRODUCTION}

Newborn calves are considered immune-naïve and agammaglobulinemic at birth, because of the synepitheliochorial placenta from dams, which prevents the passage of pathogens to the fetus during pregnancy. Even though this barrier maintains the sterility of the placental environment, it is also associated with two negative consequences for the neonate: agammaglobulinemia and absence of an immunological memory at birth (Barrington and Parrish, 2001).

Recebido em 15 de setembro de 2016

Aceito em 31 de janeiro de 2018

E-mail: camila.rcosta@usp.br 


\section{Baccili et al.}

Progesterone, prostaglandins, and the cytokines interleukin (IL)-4 and IL-10, produced by the placenta during pregnancy, are responsible for the suppression of the Th1 maternal response, which releases toxic cytokines for the fetalplacental environment. The predominance of the Th2 immune response is responsible for the susceptibility of the newborn to intracellular pathogens (Wegmannet al., 1993). Furthermore, maternal and fetal cortisol released at the end of pregnancy and during labor is responsible for stress leukogram and the decrease of the functional activity of phagocytes (Chase et al.,2008).

The immature immune system of newborn calves at birth emphasizes the critical role of passive immunity transfer from the dam. The bovine colostrum is rich in immunoglobulin G1 (IgG1), cells, and cytokines. Mononuclear leukocytes are the predominant cells in the mammary secretion, especially $\mathrm{CD}^{+} 4^{+}$macrophages $(39.6 \%)$, B lymphocytes $(24.5 \%), \quad \mathrm{CD} 4^{+} \mathrm{T}$ lymphocytes (13.8\%), and $\mathrm{CD}^{+} \mathrm{T}$ lymphocytes (19\%) (Park et al., 1992). These cells are absorbed by the newborn intestinal mucosa and have been identified in the blood stream and lymph nodes after fresh colostrum intake (Liebler-Tenorioet al., 2002; Reberet al., 2006).

The duration of immune factor presence in colostrum, especially $\operatorname{IgG} 1$, and the precocity of immune system development are the main factors in the epidemiological distribution of infectious diseases in calves. For determining the vulnerability periods, it is necessary to establish the hematological and immunological profiles of calves during early life.

Several studies have been performed to establish the normal values for hematological parameters. However, few published papers included repeated measurements of hemogram components in calves during the first 6 months of life. In addition, previous studies were performed using older technology (manual) (Brun-Hansen et al., 2006). Data on the profile of lymphocyte subsets in calves are scarce (Kampenet al., 2006). At this time, we are aware of only two international papers published on this topic, and the results may not be representative for calves under Brazilian conditions (Wilson et al., 1996; Kampenet al., 2006).
The hypothesis of this study is that variations in calves' hematological and immunological components occur during development, and these variations could indicate the window of susceptibility to antigens that are common in calf rearing. Therefore, a longitudinal study was designed to follow the cellular profile of Holstein calves from birth up to 6 months of age. This profile was evaluated by hemogram and phenotyping of the lymphocyte subsets.

\section{MATERIALS AND METHODS}

This research was approved by the Ethics Committee on Animal Use of the Faculty of Veterinary Medicine and Animal Science, University of São Paulo (Protocol \# 2305/2011).

Ten Holstein cows and their calves were sourced from a dairy farm located in Nova Odessa, São Paulo, Brazil. These cows produced 25-30L of milk per day at the peak of lactation.

The dams were vaccinated against foot and mouth disease and Brucella abortus according to the Brazilian official program. These animals were also vaccinated in the pre-partum period by subcutaneous injection of $5 \mathrm{~mL}$ of commercial multivalent vaccine containing inactivated strains of Bovine viral Diarrhea Virus (BVDV) type 1 (5960) isolated in Iowa (USA) and BVDV type 2 (53637) isolated in Ontario (USA); live/thermosensitiveBovine Herpesvirus 1 (Cooper) and Parainfluenza-3 Virus (RLB 103); live-attenuatedBovine Respiratory Syncytial Virus (strain 375) diluted in the adjuvant with "Quil A, cholesterol and amphigen." The vaccinations for bovine respiratory disease were administered twice, 8 and 4 weeks before the expected delivery dates.

Immediately after delivery, the dam was moved into a parlor where colostrum was collected aseptically from each quarter. Calves were fed with fresh colostrum from their respective dams. The calves were fed within $6 \mathrm{~h}$ of birth with $2 \mathrm{~L}$ of colostrum and with additional $2 \mathrm{Lat} 12 \mathrm{~h}$ after birth. An esophageal tube feeder was used only when the calves did not suckle from the bottle. The calves were transported from a dairy farm to the Ruminant Hospital at University of São Paulo, $140 \mathrm{~km}$, in the second week after birth. 
They were then fed with $6 \mathrm{~L}$ of milk replacer (Sprayfo ${ }^{\circledR}$ Violeta, Stolen, Deventer, Holanda), commercial feed (Ração para bezerros ${ }^{\circledR}$, Agromix, Sao Paulo, SP, Brazil), hay, mineral salt (Fosbovi 20 ${ }^{\circledR}$, Tortuga, Mairinque, SP, Brazil), and water ad libitum until weaning. The quantity of the feed was increased at the beginning of the transition period and the maximum amount was established to be $3 \mathrm{~kg} / \mathrm{day}$.

The calves were assessed before colostrum administration (D0), every 2 days until the $10^{\text {th }}$ day of life (D2 to D10), at the $15^{\text {th }}$ day after birth (D15), and then monthly up to 6 months of age (D180).

The calves were given a general clinical examination that included vital signs, hydration, ocular mucous, capillary refill, and palpation of the lymph nodes. The organ systems were evaluated when animals showed any changes in the general clinical examination and data excluded at moment presented (Feitosa, 2014).

Blood samples $(4 \mathrm{~mL})$ were collected by vein puncture of the external jugular vein, using a vacuum system, into tubes containing ethylenediamine tetraacetic acid (EDTA, $1.5 \mathrm{mg} / \mathrm{mL}$ ). All samples were transported under refrigeration in an isothermal box.

Hematological parameters were obtained using an automatic system (ABC Vet, Horiba $\mathrm{ABX}^{\circledR}$, Montpellier, FRA). Differential counting of leukocytes was performed by observing the cell morphological characteristics at 1000xmagnification (Novo et al., 2015).
The phenotyping of blood lymphocytes was performed according to the recommendations of Della Libera et al. (2012). The proportions of blood lymphocyte subsets were determined by flow cytometry (FACSCalibur ${ }^{\mathrm{TM}}$, Becton Dickinson Biosciences, San Jose, CA, USA). One hundred microliters of whole blood with EDTA was added to the flow cytometry tubes. Red blood cells (RBCs) were lysed by adding FACS Lyse Solution (BD Biosciences). Monoclonal antibodies (VMRD, Pullman, WA, USA) against various bovine leukocyte surface molecules (Table 1) were added to a final concentration of $1 \mu \mathrm{g} / \mathrm{mL}$. The samples were stained for $30 \mathrm{~min}$ at $4^{\circ} \mathrm{C}$ and washed thrice with phosphate buffered saline (PBS). Subsequently, the primary antibodies were labeled with $1 \mu \mathrm{g} / \mathrm{mL}$ fluorescein isothiocyanate - FITC, $1 \mu \mathrm{g} / \mathrm{mL}$ phycoerythrin- rPE (Invitrogen, Carlsbad, CA, USA), and $10 \mu \mathrm{g} / \mathrm{mL}$ peridinin-chlorophyll proteins - PercP (Becton Dickinson Biosciences), and incubated for $30 \mathrm{~min}$ in the dark at $4{ }^{\circ} \mathrm{C}$. The IgG1 specific antibody was conjugated with PerCP, the IgG2a specific antibody was conjugated with $\mathrm{rPE}$, and the $\operatorname{IgM}$ specific antibody was conjugated with FITC. Finally, cells were washed twice and suspended in $300 \mu \mathrm{L}$ of cold, sterile PBS.

Samples were analyzed by flow cytometry using FacsCalibur equipment (BD Biosciences, San Jose, CA, USA). Gate windows in forward angle scatter and $90^{\circ}$ light scatter were established to allow the inclusion of the lymphocyte population.

Table 1. Primary and secondaryantibodies used to identify blood mononuclear cells

\begin{tabular}{ccccc}
\hline Primary & Clones & Secondary & Isotypes & Specificity \\
\hline CD3 & MM1A & PerCP $^{\circledR}$, rat anti-mouse & IgG1 & T lymphocytes \\
CD4 & IL-A11 & rPE $^{\circledR}$, goat anti-mouse & IgG2a & T Helper \\
CD8 & BAQ111A & FITIC $^{\circledR}$, goat anti-mouse & IgM & T cytotoxic \\
CD21 & BAQ15A & & IgM & B Lymphocytes \\
\hline
\end{tabular}

Flowjo analysis software (Treestar Inc, San Carlos, USA) was used to analyze the events (50.000 cells/samples) acquired by flow cytometry. All samples were gated on forward angle and side scatter to establish the lymphocyte population. The lymphocyte subsets were analyzed based on the expression of specific fluorescence for CD3, CD4, CD8 and CD21. 


\section{Baccili et al.}

Results are reported as the percentage of gated cells that were positive for each cell surface marker. The absolute number of each lymphocyte subset was calculated by multiplication of the percentage and the total number of lymphocytes per milliliter of blood obtained from the hemogram.

Statistical analysis was performed using SPSS for Windows (International Business Machines [IBM] Corporation, Armonk, New York, USA). All variables had parametric distribution according to the Shapiro-Wilk test, except rod neutrophils and eosinophils. Theage effect was examined using repeated measures analysis of variance(ANOVA). Differences among time points were considered significant when $\mathrm{P}<0.05$.

Rod neutrophils and eosinophils were not detected at some of the evaluation time points of this research. Therefore, these parameters were determined from D0 up to D6 for rod neutrophils, and from D60 up to D180 for eosinophils. These variables had non-parametric distribution according to the Skewness-Kurtosis test. Theage effect was examined using Friedman test, but none of the tested parameters showed statistically significant difference $(\mathrm{P}<0.05)$ among time points.

\section{RESULTS}

The means and standard deviations of the erythrogram components and multiple comparisons between time points are shown in Table 2.

Sample time on RBC had decreased from D2 to D6 with an increasing trend throughout the study. Significant differences were seen between D0 (before colostrum intake)to D4 and D6 ( $\mathrm{P}<$ $0.05)$.

The maximum values for hemoglobin (HGB) and hematocrit (HCT) were observed on D0. These HCT values then decreased between D2 to D10, with a slight increase thereafter (D15 to D180). HCT values on D0 were significantly different from those on D4, D6, D8 and D10 $(\mathrm{P}<0.05)$.

The values of mean corpuscular volume (MCV), mean corpuscular hemoglobin $(\mathrm{MCH})$ and mean corpuscular hemoglobin concentration (MCHC) decreased gradually during the first 6 months of life (D0 to D180). MCV values on D0 were significantly different compared with those from D6 up to D150 $(\mathrm{P}<0.05)$, with the exception of D10. Values on D2 were different from those on D8, D30, D60, D120, D150 and D180 (P< 0.05). The mean MCV values on D4, 6, 8 and 10 differed from those on days 60,120 and $150(\mathrm{P}<$ $0.05)$. $\mathrm{MCH}$ values on $\mathrm{D} 2$ and $\mathrm{D} 8$ were different compared to those on D60 $(\mathrm{P}<0.05)$.

The means and standard deviations of the leukogram components and multiple comparisons between time points are shown in Table 3.

Total leukocytes decreased from birth up to D6, after which time, the values increased slightly and remained constant from D8 to D180. The difference between the values on D0 and those on D6 was statistically significant $(\mathrm{P}<0.05)$.

Relative and absolute values for segmented neutrophils showed some variations from D0 to D180. Relative values (\%) on D0were higher than those on D6, 30, 60, 90 and $150(\mathrm{P}<0.05)$. Absolute values $\left(\times 10^{3} / \mu \mathrm{L}\right)$ on D0 were significantly different from those on D6, D60, $\mathrm{D} 150$ and $\mathrm{D} 180(\mathrm{P}<0.05)$.

The relative and absolute values for monocytes varied slightly from D0 to D180. There were no statistically significant differences between the time points, despite the slight variations observed during this study. Relative and absolute lymphocyte values increased from D0 up to D180, and displayed some variations on D6, D30-D90 and D150-180. The number (\%) of lymphocytes on D0 was lower than that on D6, D15, D30, D60, D90, D150 and D180 (P<0.05).

Rod neutrophils and eosinophils were not detected at some of the time points included in this study. The minimum and maximum values observed for rod neutrophils were $1 \%(0.1 \times$ $\left.10^{3} / \mu \mathrm{L}\right)$ on D6 and $3.8 \%\left(0.6 \times 10^{3} / \mu \mathrm{L}\right)$ on D2, respectively. Eosinophil numbers varied between $1 \%\left(0.1 \times 10^{3} / \mu \mathrm{L}\right)$ on $\mathrm{D} 90$ and $3 \%(0.2 \times$ $10^{3} / \mu \mathrm{L}$ ) on $\mathrm{D} 150$. There were no statistically significant differences between time points for these parameters.

The means and standard deviations for lymphocyte subsets and multiple comparisons between time points are shown in Figure 1. Variations were detected in the proportions of $\mathrm{CD}^{+}$and $\mathrm{CD} 21^{+}$cells. 
Hematological and immunological...

Table 2. Means and standard deviations of erythrogram components of Holstein calves from birth up to six months of age

\begin{tabular}{ccccccc}
\hline Moments & $\begin{array}{c}\text { RBC } \\
\left(\times 10^{6} / \mu \mathrm{L}\right)\end{array}$ & $\begin{array}{c}\text { HGB } \\
(\mathrm{g} / \mathrm{dL})\end{array}$ & $\begin{array}{c}\text { HCT } \\
(\%)\end{array}$ & $\begin{array}{c}\text { MCV } \\
(\mathrm{fL})\end{array}$ & $\begin{array}{c}\text { MCH } \\
(\mathrm{pg})\end{array}$ & $\begin{array}{c}\text { MCHC } \\
(\%)\end{array}$ \\
\hline D0 & $8.5 \pm 1.3^{\mathrm{a}}$ & $12.5 \pm 2.3^{\mathrm{a}}$ & $39 \pm 6^{\mathrm{a}}$ & $46 \pm 1^{\mathrm{af}}$ & $14.5 \pm 1.3^{\mathrm{ab}}$ & $32 \pm 2^{\mathrm{a}}$ \\
D2 & $7.2 \pm 1.3^{\mathrm{ab}}$ & $10.5 \pm 1.9^{\mathrm{a}}$ & $31 \pm 5^{\mathrm{ab}}$ & $43 \pm 1^{\mathrm{ac}}$ & $14.5 \pm 0.7^{\mathrm{a}}$ & $33 \pm 2^{\mathrm{a}}$ \\
D4 & $6.8 \pm 1.4^{\mathrm{b}}$ & $10.0 \pm 1.8^{\mathrm{a}}$ & $30 \pm 4^{\mathrm{b}}$ & $42 \pm 2^{\mathrm{acd}}$ & $13.8 \pm 1.7^{\mathrm{ab}}$ & $33 \pm 4^{\mathrm{a}}$ \\
D6 & $7.1 \pm 1.4^{\mathrm{b}}$ & $9.3 \pm 2.5^{\mathrm{a}}$ & $30 \pm 4^{\mathrm{b}}$ & $42 \pm 2^{\mathrm{cde}}$ & $13.2 \pm 3.0^{\mathrm{ab}}$ & $31 \pm 8^{\mathrm{a}}$ \\
D8 & $7.5 \pm 1.2^{\mathrm{ab}}$ & $10.2 \pm 1.3^{\mathrm{a}}$ & $31 \pm 4^{\mathrm{b}}$ & $41 \pm 1^{\mathrm{de}}$ & $13.5 \pm 0.9^{\mathrm{a}}$ & $33 \pm 4^{\mathrm{a}}$ \\
D10 & $7.7 \pm 1.1^{\mathrm{ab}}$ & $9.7 \pm 1.6^{\mathrm{a}}$ & $31 \pm 4^{\mathrm{b}}$ & $41 \pm 2^{\mathrm{ae}}$ & $13.3 \pm 1.1^{\mathrm{ab}}$ & $33 \pm 3^{\mathrm{a}}$ \\
D15 & $8.5 \pm 1.2^{\mathrm{ab}}$ & $10.0 \pm 1.6^{\mathrm{a}}$ & $33 \pm 3^{\mathrm{ab}}$ & $40 \pm 3^{\mathrm{bcde}}$ & $12.1 \pm 1.8^{\mathrm{ab}}$ & $31 \pm 5^{\mathrm{a}}$ \\
D30 & $10 \pm 1.4^{\mathrm{ab}}$ & $11.1 \pm 1.6^{\mathrm{a}}$ & $36 \pm 6^{\mathrm{ab}}$ & $37 \pm 3^{\mathrm{bde}}$ & $11.7 \pm 1.2^{\mathrm{ab}}$ & $31 \pm 3^{\mathrm{a}}$ \\
D60 & $9.8 \pm 1.7^{\mathrm{ab}}$ & $10.0 \pm 2.0^{\mathrm{a}}$ & $34 \pm 6^{\mathrm{ab}}$ & $37 \pm 2^{\mathrm{b}}$ & $10.6 \pm 1.1^{\mathrm{b}}$ & $29 \pm 3^{\mathrm{a}}$ \\
D90 & $9.2 \pm 1.8^{\mathrm{ab}}$ & $10.8 \pm 1.1^{\mathrm{a}}$ & $33 \pm 4^{\mathrm{ab}}$ & $38 \pm 4^{\mathrm{bcde}}$ & $12.3 \pm 1.6^{\mathrm{ab}}$ & $33 \pm 2^{\mathrm{a}}$ \\
D120 & $9.6 \pm 0.5^{\mathrm{ab}}$ & $10.1 \pm 0.6^{\mathrm{a}}$ & $33 \pm 5^{\mathrm{ab}}$ & $36 \pm 3^{\mathrm{b}}$ & $11.2 \pm 1.2^{\mathrm{ab}}$ & $31 \pm 2^{\mathrm{a}}$ \\
D150 & $9.7 \pm 1.7^{\mathrm{ab}}$ & $10.1 \pm 1.2^{\mathrm{a}}$ & $34 \pm 6^{\mathrm{ab}}$ & $36 \pm 2^{\mathrm{bg}}$ & $10.7 \pm 2.1^{\mathrm{ab}}$ & $29 \pm 2^{\mathrm{a}}$ \\
D180 & $9.2 \pm 2.1^{\mathrm{ab}}$ & $9.7 \pm 1.5^{\mathrm{a}}$ & $33 \pm 7^{\mathrm{ab}}$ & $33 \pm 9^{\mathrm{bdef}}$ & $10.3 \pm 2.0^{\mathrm{ab}}$ & $29 \pm 5^{\mathrm{a}}$
\end{tabular}

(RBC) red blood cells; (MCV) mean corpuscular volume; $(\mathrm{MCH})$ mean corpuscular hemoglobin; (MCHC) mean corpuscular hemoglobin concentration. Lower case letters in the same column show difference between moments $(\mathrm{P}<0.05)$ using ANOVA for repeated measure.

Table 3. Means and standard deviations of leukogram components of Holstein calves from birth up to six months of age

\begin{tabular}{cccccccc}
\hline Moments & $\begin{array}{c}\text { Leukocytes } \\
\left(\times 10^{3} / \mu \mathrm{L}\right)\end{array}$ & \multicolumn{2}{c}{ Segmented Neutrophils } & \multicolumn{2}{c}{ Monocytes } & \multicolumn{2}{c}{ Lymphocytes } \\
& $\left(\times 10^{3} / \mu \mathrm{L}\right)$ & $(\%)$ & $\left(\times 10^{3} / \mu \mathrm{L}\right)$ & $(\%)$ & $\left(\times 10^{3} / \mu \mathrm{L}\right)$ \\
\hline D0 & $15 \pm 4^{\mathrm{a}}$ & $62 \pm 12^{\mathrm{a}}$ & $9.04 \pm 3^{\mathrm{a}}$ & $11 \pm 1^{\mathrm{a}}$ & $1.45 \pm 0.48^{\mathrm{a}}$ & $25 \pm 10^{\mathrm{a}}$ & $3.52 \pm 1.99^{\mathrm{a}}$ \\
D2 & $13 \pm 4^{\mathrm{ab}}$ & $54 \pm 19^{\mathrm{ab}}$ & $7.49 \pm 4^{\mathrm{ab}}$ & $9 \pm 2^{\mathrm{a}}$ & $1.22 \pm 1.13^{\mathrm{a}}$ & $33 \pm 14^{\mathrm{ab}}$ & $4.12 \pm 1.64^{\mathrm{a}}$ \\
D4 & $10 \pm 2^{\mathrm{ab}}$ & $34 \pm 19^{\mathrm{ab}}$ & $3.58 \pm 2^{\mathrm{ab}}$ & $15 \pm 1^{\mathrm{a}}$ & $1.57 \pm 0.53^{\mathrm{a}}$ & $44 \pm 14^{\mathrm{ab}}$ & $4.27 \pm 1.17^{\mathrm{a}}$ \\
D6 & $9 \pm 4^{\mathrm{b}}$ & $31 \pm 6^{\mathrm{b}}$ & $2.99 \pm 1^{\mathrm{b}}$ & $14 \pm 2^{\mathrm{a}}$ & $1.37 \pm 0.98^{\mathrm{a}}$ & $54 \pm 9^{\mathrm{b}}$ & $4.39 \pm 1.29^{\mathrm{a}}$ \\
D8 & $11 \pm 4^{\mathrm{ab}}$ & $37 \pm 15^{\mathrm{ab}}$ & $4.52 \pm 3^{\mathrm{ab}}$ & $13 \pm 2^{\mathrm{a}}$ & $1.47 \pm 0.84^{\mathrm{a}}$ & $49 \pm 15^{\mathrm{ab}}$ & $4.87 \pm 1.13^{\mathrm{a}}$ \\
D10 & $12 \pm 4^{\mathrm{ab}}$ & $46 \pm 11^{\mathrm{ab}}$ & $5.88 \pm 3^{\mathrm{ab}}$ & $10 \pm 2^{\mathrm{a}}$ & $1.33 \pm 0.61^{\mathrm{a}}$ & $43 \pm 13^{\mathrm{ab}}$ & $4.55 \pm 1.15^{\mathrm{a}}$ \\
D15 & $10 \pm 4^{\mathrm{ab}}$ & $35 \pm 14^{\mathrm{ab}}$ & $3.85 \pm 3^{\mathrm{ab}}$ & $15 \pm 2^{\mathrm{a}}$ & $1.39 \pm 0.47^{\mathrm{a}}$ & $49 \pm 10^{\mathrm{b}}$ & $4.94 \pm 1.93^{\mathrm{a}}$ \\
D30 & $11 \pm 2^{\mathrm{ab}}$ & $25 \pm 13^{\mathrm{b}}$ & $2.88 \pm 2^{\mathrm{ab}}$ & $14 \pm 1^{\mathrm{a}}$ & $1.62 \pm 0.60^{\mathrm{a}}$ & $56 \pm 13^{\mathrm{b}}$ & $6.37 \pm 1.22^{\mathrm{a}}$ \\
D60 & $11 \pm 3^{\mathrm{ab}}$ & $38 \pm 9^{\mathrm{b}}$ & $4.39 \pm 2^{\mathrm{b}}$ & $15 \pm 1^{\mathrm{a}}$ & $1.64 \pm 0.46^{\mathrm{a}}$ & $43 \pm 5^{\mathrm{b}}$ & $5.06 \pm 1.48^{\mathrm{a}}$ \\
D90 & $12 \pm 4^{\mathrm{ab}}$ & $37 \pm 16^{\mathrm{b}}$ & $4.74 \pm 3^{\mathrm{ab}}$ & $14 \pm 1^{\mathrm{a}}$ & $1.59 \pm 0.35^{\mathrm{a}}$ & $45 \pm 13^{\mathrm{b}}$ & $5.12 \pm 1.35^{\mathrm{a}}$ \\
D120 & $10 \pm 3^{\mathrm{ab}}$ & $38 \pm 14^{\mathrm{ab}}$ & $4.10 \pm 2^{\mathrm{ab}}$ & $13 \pm 2^{\mathrm{a}}$ & $1.49 \pm 1.19^{\mathrm{a}}$ & $44 \pm 9^{\mathrm{ab}}$ & $4.3 \pm 0.99^{\mathrm{a}}$ \\
D150 & $9 \pm 4^{\mathrm{ab}}$ & $33 \pm 13^{\mathrm{b}}$ & $2.96 \pm 2^{\mathrm{b}}$ & $11 \pm 1^{\mathrm{a}}$ & $1.12 \pm 0.69^{\mathrm{a}}$ & $50 \pm 10^{\mathrm{b}}$ & $4.51 \pm 2.62^{\mathrm{a}}$ \\
D180 & $10 \pm 4^{\mathrm{ab}}$ & $31 \pm 11^{\mathrm{ab}}$ & $2.99 \pm 2^{\mathrm{b}}$ & $10 \pm 1^{\mathrm{a}}$ & $1,11 \pm 0,69^{\mathrm{a}}$ & $54 \pm 11^{\mathrm{b}}$ & $5.15 \pm 2.18^{\mathrm{a}}$ \\
\hline
\end{tabular}

Lower case letters in the same column show difference between moments $(\mathrm{P}<0.05)$ using ANOVA for repeated measure. 

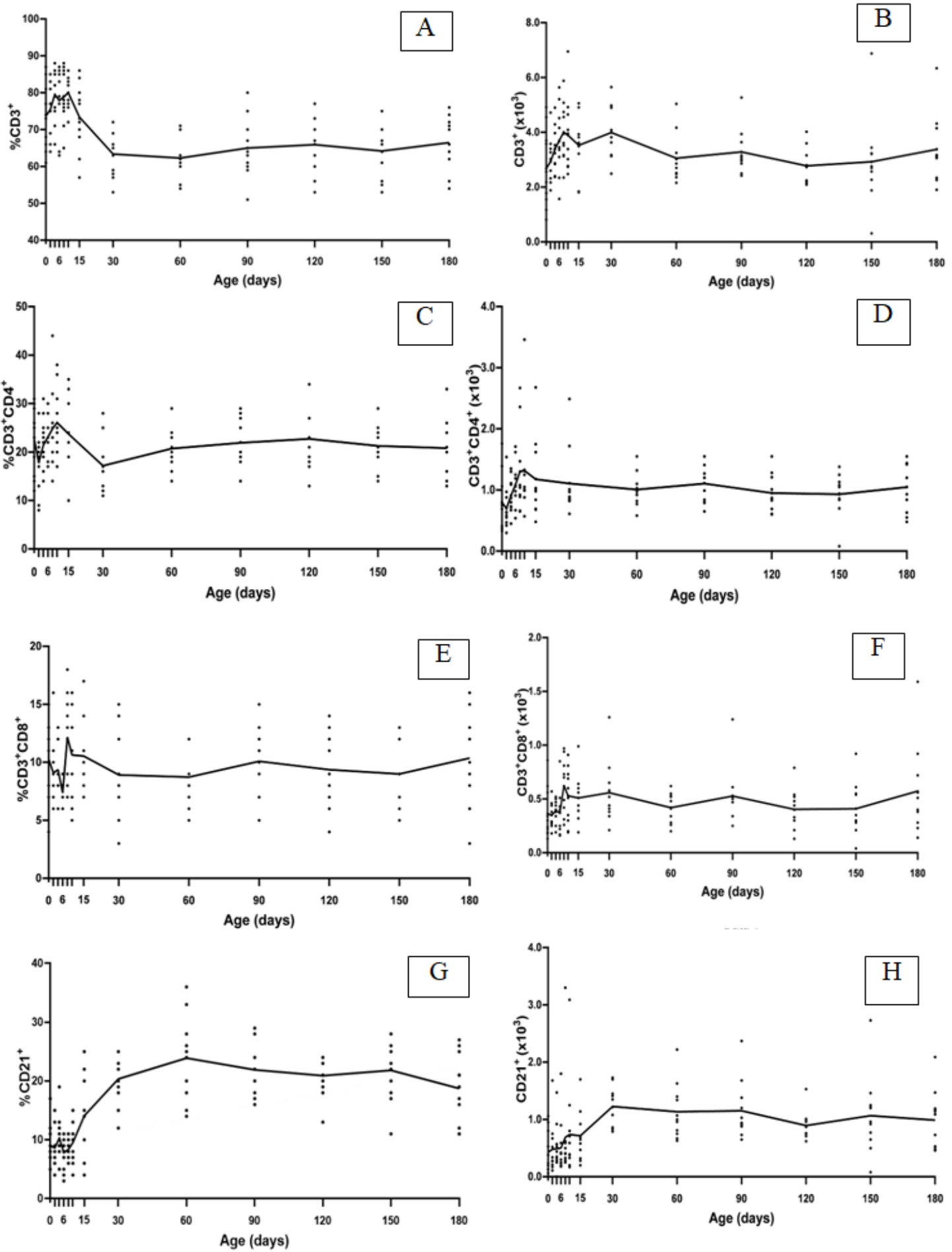

Figure 1. Mean and individual values of $\mathrm{T}$ and $\mathrm{B}$ lymphocytes population in blood of Holstein calves from birth up to six months of age 
The mean relative values of $\mathrm{CD}^{+} \mathrm{T}$ lymphocytes did not change substantially in the first 10 days of life and then decreased (D15). The proportion of $\mathrm{CD}^{+}(\%)$ at $\mathrm{D} 10$ was higher than that observed on D30, D60, D90, D150 and D180 $(\mathrm{P}<0.05)$. There were no statistically significant differences in the absolute values of $\mathrm{CD}^{+}$cells between time points.

The mean of absolute and relative values of the subsets $\mathrm{CD}^{+}$and $\mathrm{CD} 8^{+}$showed slight variations during the course of the study. There were no statistically significant differences between time points for these parameters.

The proportions (\%) and absolute values of CD $21^{+}$lymphocytes increased significantly from D0 up to D30-D180. Differences in both parameters were detected between the early time points of D0, D2, D4, D8, D15 and the later time points of D30, D60, D90, D120 and D150.

By clinical parameters, all calves were healthy immediately after birth (D0). Navel inflammation and diarrhea were the most frequently observed disease conditions during the first fifteen days after birth. The frequencies of navel inflammation were $20 \%(2 / 10)$ from D2 up to D10 and increased to $50 \%$ by D15 $(5 / 10$,). Four cases of diarrhea were detected only on D15.

\section{DISCUSSION}

This study followed the hematological and immunological profiles of Holstein calves from birth up to 180 days of life.

Hemoconcentrationwas observed at birth, higher values of RBC, HGB and HCT in the first days of life are related of a physiological hemoconcentration due to fetal growth in a placental environment with low concentrations of $\mathrm{O}_{2}$. The components of the erythrogram are consistent with established reference ranges, according to Novo et al., (2015), Benesiet al. (2012a); Brun-Hansen et al., (2006). The subsequent decrease values is associated with the higher oncotic pressure and plasma dilution after colostrum administration. Moreover, low serum iron levels in neonates can compromise erythropoiesis (Mohriet al., 2004; Mohriet al., 2007).
The MCV values of newborn calves were highest at birth (46 fL) and then decreased subsequently. Erythrocyte size also decreased with advancing age, which probably occurs through the replacement of RBCs containing fetal HGB by smaller RBCs containing adult HGB (Knowles et al., 2000; Lee et al., 1971). The decrease in hematimetric rates was concomitant with the increase of RBCs from the $10^{\text {th }}$ day of life. These data are in agreement with variations reported in previous studies (Brun-Hansen et al., 2006).

The leukocytosis by neutrophilia observed around birth might be caused by the increase of maternal and fetal cortisol at the end of pregnancy and during labor. No evidence of eosinopenia profile was reported (Fagliariet al., 1998; Benesiet al., 2012b), since eosinophils cell concentration of calves are in small numbers in the blood of both young calves and adult animals. Transient increase in circulating neutrophils occurs because of the release of bone marrow cells and the marginal compartment for blood circulation. Furthermore, lower expression of L-selectin adhesion molecules on the surface of these cells in the presence of high cortisol levels has been reported (Nagahataet al., 2000). Despite the reported neutrophilia, it is worth noting that the phagocytosis and bactericidal activity are decreased in neonate calves (Hauser et al., 1986).

Leukogram analysis and phenotyping of lymphocyte subsets allowed us to conclude that the total number of lymphocytes increased because of the increase in the proportion of $\mathrm{CD} 21^{+} \mathrm{B}$ cells after 30 days of life. The relative level of B lymphocytes detected in the first week after birth was low (9\%), a value slightly higher than the mean value of $4 \%$ reported by Kampenet al. (2006).

The cellular profile in the calves during the first weeks of life can be influenced by variations in the levels of progesterone, prostaglandin, and cytokines IL-4 and IL-10 transferred from dams to newborn calves through pregnancy (Chase et al., 2008). Despite the Th2 cytokine profile at birth, the increase in the number of $\mathrm{B}$ lymphocytes presenting $\mathrm{CD} 21^{+}$receptor, which is expressed only in activated B cells, was observed only on the $30^{\text {th }}$ day of life. 
The late activation of B cells in neonates may be related to the low number of dendritic cells and low expression of major histocompatibility complex (MHC) class II by monocytes during the neonatal period (Reberet al., 2008a; Reberet al., 2008b). Once a pathogen is recognized, it is internalized and processed by antigen-presenting cells (APCs). The peptides generated by APCs are expressed on the membranes of MHC II cells, which present the peptide to helper $\mathrm{T}$ lymphocytes $\left(\mathrm{CD}^{+}\right)$. The binding between MHC II and $\mathrm{T}$ lymphocyte receptor triggers events that result in the clonal expansion of $\mathrm{T}$ helper cells and enhanced cytokine production, which stimulate the proliferation of B lymphocytes and their differentiation to memory cells and plasma cells, which in turn produce antigen-specific immunoglobulins (McHeyzer-Williams, 2003).

Activated B cells could also act as APCs (McHeyzer-Williams, 2003). However, the reduced density of the $\mathrm{CD} 21^{+}$population in the first month of life can negatively impact $\mathrm{B}$ cell self-stimulation.

B cells migrate from the bone marrow to the secondary lymphoid tissues, where they go through the maturation process. Initially, naïve B cells are located in the primary lymphoid follicles, where they bind antigens and become activated. Then, the cells migrate to the germinal center portion for the selection and clonal expansion of antigen-specific B cells, where B lymphocytes are transformed to antibodysecreting plasma cells and memory B cells. The germinal center grows in size as the immune response is triggered by pathogens. It regresses and finally disappears when the infection is resolved. Germinal centers are present in the lymph nodes for about 3-4 weeks after initial antigen exposure, and subsequently leave via the efferent lymphatic vessels (Rudinand Thompson, 1998). The increase in activated B lymphocytes observed in this study could have been triggered by antigenic exposure. This phenomenon indicates that the maturation of specific immune system progresses in small steps from birth until puberty. Kampenet al. (2006) and Chatthaet al. (2009) also reported a similar increase in lymphocytes after 30 days.

The low number of B lymphocytes may be responsible for colonization and infection by extracellular microorganisms that cause diarrhea and navel inflammation. These diseases were the main cause of data exclusion in this experiment on D8, D10 e D15.

The proportion of $\mathrm{CD}^{+} \mathrm{T}$ lymphocytes decreased from the $10^{\text {th }}$ day of life. Variations in the proportions of $\mathrm{CD}^{+} \mathrm{T}$ lymphocytes could not be compared with those observed in the other studies owing to the scarcity of longitudinal studies evaluating the expression of this receptor from birth up to 6 months of age.

The proportions of $\mathrm{CD}^{+}$and $\mathrm{CD}^{+} \mathrm{T}$ lymphocytes were stable throughout the study period, with values of $23 \%$ and $10 \%$ at birth, and $21 \%$ and $10 \%$, respectively, at 6 months of age. A similar proportion has been reported in earlier studies (Allen et al., 1996; Ayoub and Yang, 1996; Kampenet al., 2006; Kulberget al., 2004; Wilson et al., 1996).

Hematologic and immune components of calves, as determined by hemoconcentration, stress leukogram, and the predominance of $\mathrm{CD}^{+} \mathrm{T}$ cells, varied with age, especially in the first month of life, when compared to $\mathrm{CD} 21^{+}$Bcells until 30 days of age. Subsequently, the lymphocyte populations increased due to the increase in $\mathrm{CD} 21^{+} \mathrm{B}$ cells.

Variation in the cell populations indicates that the neonatal period is a phase of increased susceptibility to infectious diseases. Therefore, extra care is neededto maintain the health and survival of the calves during this phase (Murray and Leslie, 2013).

\section{CONCLUSION}

This research highlights the neonatal period as a critical stage in calf rearing. The study results also indicate that hematological profiles and subsets of lymphocytes of calves were functional and able to generate immune response in the calves after 30 days of life.

\section{ACKNOWLEDGEMENTS}

This work was supported by São Paulo Research Foundation [grant number 2010/015865-9]. 


\section{REFERENCES}

ALLEN, L.J.; KABBUR, M.B.; CULLOR, J.S. et al. Alterations in blood lymphocyte subpopulations and hematologic values in neonatal calves after administration of a combination of multiple-antigen vaccines. J. Am. Vet. Med. Assoc., v.209, p.638-642, 1996.

AYOUB, I.A.; YANG, T.J. Age-dependent changes in peripheral blood lymphocyte subpopulations in cattle: a longitudinal study. Dev. Comp. Immunol., v.20, p.353-363, 1996.

BARRINGTON, G.M.; PARISH, S.M. Bovine neonatal immunology. Vet. Clin. N. Am. Food Anim. Pract., v.17, p.463-476, 2001.

BENESI, F.J.; TEIXEIRA, C.M.C.; LEAL, M.L.R. et al. Leukograms of healthy Holstein calves within the first month of life. Pesqui. Vet. Bras., v.32, p.352-356, 2012b.

BENESI, F.J.; TEIXEIRA, C.M.C.; LISBOA, J.A.N. et al. Eritrograma de bezerros sadios, da raça Holandesa, no primeiro mês de vida. Pesqui. Vet. Bras., v.32, p.357-360, $2012 \mathrm{a}$.

BRUN-HANSEN, H.C.; KAMPEN, A.H.; LUND, A. Hematologic values in calves during the first 6 months of life. Vet. Clin. Pathol., v.35, p.182-187, 2006.

CHASE, C.C.; HURLEY, D.J.; REBER, A.J. Neonatal immune development in the calf and its impact on vaccine response.Vet. Clin. N. Am. Food Anim. Pract., v.24, p.87-104, 2008.

CHATTHA, K.S.; FIRTH, M.A.; HODGINS, D.C.; SHEWEN, P.E. Age related variation in expression of CD21 and CD32 on bovine lymphocytes: a cross-sectional study.Vet. Immunol. Immunopathol.,v.130, p.70-78, 2009.

DELLA LIBERA, A.M.M.P.; BLAGITZ, M.G.; BATISTA, C.F. et al. Quantification of B cells and $\mathrm{T}$ lymphocyte subsets in bovine leukemia virus infected dairy cows. Semina, v.33, p.14871494, 2012.

FAGLIARI, J.J.; SANTANA, A.E.; CAMPOS FILHO, E.; CURI, P.R. Blood constituents of the newborn Nelore cattle (Bosindicus), Holstein cattle (Bostaurus), and Murrah buffalo (Bubalusbubalis). Arq. Bras. Med. Vet. Zootec., v.50, p.253-262, 1998.
FEITOSA, F.L.F. Semiologia de recém-nascidos ruminantes e equídeos.Semiologia veterinária: a arte do diagnóstico. 3.ed. São Paulo: Roca, 2014. $627 \mathrm{p}$.

HAUSER, M.A.; KOOB, M.D.; ROTH, J.A. Variation of neutrophil function with age in calves. Am. J. Vet. Res., v.47, p.152-153, 1986.

KAMPEN, A.H., OLSEN, I.; TOLLERSRUD, T.; STORSET, A.K. et al. Lymphocyte subpopulations and neutrophil function in calves during the first 6 months of life. Vet. Immunol. Immunopathol., v.113, p.53-63, 2006.

KNOWLES, T.G.; EDWARDS, J.E.; BAZELEY, K.J. et al. Changes in the blood biochemical and haematological profile of neonatal calves with age.Vet. Rec., v.147, p.593598,2000 .

KULBERG, S.; BOYSEN, P.; STORSET, A.K. Reference values for relative numbers of natural killer cells in cattle blood. Dev. Comp. Immunol., v.28, p.941-948, 2004.

LEE, C.K.; ODELL, G.V.; ELIOT, F.P. et al. Postnatal loss of bovine fetal hemoglobin. Am. J. Vet. Res.v.32, p.1039, 1971

LIEBLER-TENORIO, E.M.; RIEDELCASPARI, G.; POHLENZ, J.F. Uptake of colostral leukocytes in the intestinal tract of newborn calves. Vet. Immunol. Immunopathol., v.85, p.33-40, 2002.

MCHEYZER-WILLIAMS, M.G. B cells as effectors. Curr. Opin. Immunol.,v.15, p.354-361, 2003.

MOHRI, M.; SARRAFZADEH, F.; SEIFI, H. A.; FARZANEH, N. Effects of oral iron supplementation on some haematological parameters and iron biochemistry in neonatal dairy calves.Comp. Clin. Pathol., v.13, p.9-42, 2004.

MOHRI, M.; SHARIF, K.; EIDI, S. Hematology and serum biochemistry of Holstein dairy calves: age related changes and comparison with blood composition in adults. Res. Vet. Sci., v.83, p.3039, 2007.

MURRAY, C.F.; LESLIE, K.E. Newborn calf vitality: risk factors, characteristics, assessment, resulting outcomes and strategies for improvement. Vet. J., v.198, p.322-328, 2013. 
NAGAHATA, H.; HIGUCHI, H.; YAMASHIKI, N.; YAMAGUCHI. M. Analysis of the functional characteristics of L-selectin and its expression on normal and CD18-deficient bovine neutrophils.Immunol.CellBiol., v.78, p.264-271, 2000.

NOVO, S.M.F.; FREITAS, R.L.; SILVA, C.P.D.C. et al. Hematological adaptation in Holstein calves during the neonatal period. Braz. J. Vet. Res. Anim. Sci, v.52, p.212-216, 2015.

PARK, Y.H.; FOX, L.K.; HAMILTON, M.J.; DAVIS, W.C. Bovine Mononuclear leukocyte subpopulations in peripheral blood and mammary gland secretions during lactation. $J$. Dairy Sci., v.75, p.998-1006, 1992.

REBER, A.J.; DONOVAN D.C.; GABBARD, J. et al. Transfer of maternal colostral leukocytes promotes development of neonatal immune system: I- effects on monocyte lineage cells. Vet. Immunol. Immunopathol.,v.123, p.186-196, 2008a.

REBER, A.J.; DONOVAN D.C.; GABBARD, J. et al. Transfer of maternal colostral leukocytes promotes development of neonatal immune system: II- Effects on neonatal lymphocytes. Vet. Immunol. Immunopathol.v.123, p.305-313, $2008 b$
REBER, A.J.; LOCKWOOD, A.; HIPPEN, A.R.; HURLEY, D.J. Colostrum induced phenotypic and trafficking changes in maternal mononuclear cells in a pheripheral blood leukocyte model for study of leukocyte transfer to the neonatal calf. Vet. Immunol. Immunopathol.,v.109, p.139-150, 2006.

RUDIN, C.M.; THOMPSON, C.B. B-Cell Development and maturation. Semin. Oncol.,v.25, p.435-446, 1998.

WEGMANN, T.G.; LIN, H.; GUILBERT, L.; MOSMANN, T.R. Bidirectional cytokine interactions in the maternal-fetal relationship: is successful pregnancy a $\mathrm{TH} 2$ phenomenon? Immunoly. Today, v.14, p.353-356, 1993.

WILSON, R.A.; ZOLNAI, A.; RUDAS, P.; FRENYO, L.V. T-cell subsets in blood and lymphoid tissues obtained from fetal calves, maturing calves, and adult bovine. Vet. Immunol. Immunopathol.,v.53, p.49-60, 1996. 